\title{
Legal Protection Of Victims In The Crime Of Rapes
}

\author{
Evi Yulianti*) and Achmad Sulchan**) \\ *) Civil Servant Email: eviyuliantisakir@gmail.com \\ **) Universitas Islam Sultan Agung (UNISSULA) Semarang
}

\begin{abstract}
The purpose of this study is to identify and analyze the legal protection of victims in the crime of rape, and to identify and analyze the obstacles and solutions to the legal protection of victims in the crime of rape. This study uses a normative juridical approach, which in this case relates to the legal protection of victims in the crime of rape with descriptive analytical research specifications. The data used are primary and secondary data which will be analyzed qualitatively. The research problems were analyzed using law enforcement theory, legal certainty and Islamic justice theory. The results of the study concluded that the protection of victims of the crime of rape in addition to experiencing physical suffering also experienced psychological suffering which took a long time to recover. Considering that the suffering experienced by the victims of the crime of rape is not light and it takes a long time to recover, the law enforcement officers are obliged to provide protection for the victims of the crime of rape. The obstacles that arise in the legal protection of the rights of victims in the process of resolving criminal cases: a) The criminals themselves, where the perpetrators of the crime are very good at committing crimes so that they are not caught or not caught; b) The attitude of the community, where the attitude of the community is indifferent in dealing with crimes that occur in their environment, so that people are less sensitive in dealing with crimes that occur; c) The compensation given by the perpetrator to the victim is not in accordance with what the victim expects because of the economic limitations of the perpetrator of the crime; d) For immaterial losses in criminal cases it cannot be done. The solution to the legal protection of victims in the crime of rape is the rehabilitation of victims of the crime of rape.
\end{abstract}

Keywords: Legal Protection; Crime; Rape.

\section{Introduction}

Crime can be interpreted criminologically and juridically. Crime in the sense of criminology is a human act that tarnishes the basic norms of society. This is intended as the actions of individuals who violate the rules that live and thrive in society. Juridical crime, i.e. an evil act or evil act in the sense of criminal law means that the crime is formulated in criminal regulations. ${ }^{1}$ For modern countries, the desire to effectively guarantee the rights of citizens and regulate the orderly state administration has encouraged every State to adopt constitutionalism, including legal arrangements regarding the protection of victims of the crime of rape. ${ }^{2}$ The settlement of criminal cases is carried out through the evidentiary process, namely

\footnotetext{
${ }^{1}$ Yusril I A, Bambang Tri Bawono and Ira Alia Maerani, Criminal Investigation of Motorcycle Stealing Goods. Law Development Journal ISSN : 2747-2604 Volume 3 Issue 1, March 2021, (169 - 174). file:///C:/Users/win10e/Downloads/14866-35234-1-PB.pdf

${ }^{2}$ Adhe I smail A, Constitutionalism Concept in Implementation of Indonesian State Administration. Jurnal Daulat Hukum Volume 4 Issue 2, June 2021 ISSN: 2614-560X. http://jurnal.unissula.ac.id/index.php/RH/article/view/15737/5567.
} 
the prosecution process which is carried out directly in an experiment. ${ }^{3}$ In judicial practice, the process always begins with an arrest, detention, then being prosecuted by the public prosecutor, which ends with a judge's decision. ${ }^{4}$

The resolution of conflicts that occur in the community can be done with two options, namely litigation and non-litigation. Litigation is a way of solving problems through the Court, while non-litigation is a way of solving problems outside the Court. In the perspective of criminal law in Indonesia, it is familiar with the settlement of criminal cases outside the court, or often referred to as Alternative Dispute Resolution. ${ }^{5}$

The type of loss suffered by the victim is not only in the form of material such as the costs incurred for healing physical wounds, but also immaterial losses that are difficult, maybe even not assessed in money, for example loss of mental balance, loss of enthusiasm for life, and self-confidence due to anxiety and the fear of the shadows he had been through. Therefore, based on the law in force in Indonesia, the victim can claim damages or compensation against the convict. ${ }^{6}$

Attention and protection of the interests of victims of the crime of rape who claim the loss, either through the criminal justice process (litigation/adjudication) or through certain social care facilities, is an absolute part that needs to be considered in criminal law policies and social policies, both by executive institutions, legislative, judicial and social institutions. Based on the goal (oogmerk) to realize equitable distribution of justice and general welfare, the rights of victims of rape to be protected are basically an integral part of human rights (human rights, mensenrecht) in the field of social security. ${ }^{7}$

The factors of the occurrence of rape due to several things; 1) Place. The environment where the victim (child) and the perpetrator are very influential on the occurrence of the crime of rape usually the perpetrator of rape does not have the intention to rape the victim, but because the victim is in a quiet or dark place or because of the bedroom factor that does not have restrictions and is added to the factor of opportunity, then there is a high probability of rape. 2) Time. Our presumption that rape only occurs at night or when it's quiet has been dispelled by a new fact that in the case of rape against minors, rape can also occur during the day when the child (victim) is playing or is at home alone. . This condition is used by the perpetrator to take advantage of the child's innocence by using threats of violence or persuasion. 3) Pornography.

\footnotetext{
${ }^{3}$ Ardito, Y P, Umar Ma'ruf and Aryani Witasari. Implementation of Criminal Action Prosecution Online in Realizing Principle of Fast Prosecution, Simple \& Low Cost, Jurnal Daulat Hukum, Volume 4 Issue 2, June 2021 ISSN: 2614-560X. http://jurnal.unissula.ac.id/index.php/RH/article/view/15737/5567. ${ }^{4}$ Feri, S W, and Arpangi. Settlement Policy of Criminal Actions which Performed by Children through Penal Mediation. Jurnal Daulat Hukum Volume 4 Issue 2, June 2021 ISSN: 2614-560X. http://jurnal.unissula.ac.id/index.php/RH/article/view/15737/5567.

${ }^{5}$ Arif Septria Hendra Saputra, Gunarto, Lathifah Hanim, Penerapan Restorative Justice Sebagai Alternatif Penyelesaian Tindak Pidana Penganiayaan Di Satreskrim Polsek Lasem, Jurnal Daulat Hukum, Vol.I No.1, March 2018.

${ }^{6}$ Romli Atmasasmita, Kepala Selekta Hukum Pidana dan Krimonologi, Bandung: Mandar Maju, 1995, p. 106.

${ }^{7}$ Lilik Mulyadi, Kapita Selekta Hukum Pidana Krimonologi dan Viktimologi, Jakarta: Djambatan, 2004, p. 135.
} 
Pornography is divided into two parts, namely printed pornography consisting of pornographic books, pornographic magazines, and electronic pornography which consists of films containing sex scenes, all of which expose/show images that can arouse lust for everyone who sees them. The rise or free rental of compat disc porn videos lately has also poisoned the soul and morals of the community. 4) Alcoholism. Alcohol can damage a person's psyche so that the person cannot control himself or cause a loss of self-restraint. In this drunken condition and irresistible sexual desire, it is not uncommon for underage children to be used as a place to release their lust. In addition to internal and external factors from both the perpetrator and the victim as described above. There is one factor that is no less important, namely, the opportunity factor. Although the internal and external factors owned by the victim and the perpetrator are so large, without the opportunity, the crime of rape against minors cannot occur.

One of the efforts to overcome the prevalence of rape victims is in empowering women, namely participating in the program of the Ministry of Women's Empowerment and Child Protection, namely: 1) improving the quality of life of women and protecting children, 2) strengthening gender mainstreaming institutions, 3) harmonizing policies to improve quality of children and women, 4) increased participation and gender equality in development. ${ }^{8}$

The police is a subsystem in the criminal justice system that is sufficient to determine the success and work of the entire system in providing services to the public. ${ }^{9}$ Legal protection for children as victims of crime can include forms of protection that are abstract (indirect) or concrete (direct). Abstract Protection is basically a form of protection that can only be enjoyed or felt emotionally (psychically), such as a sense of satisfaction (satisfaction). Meanwhile, concrete protection is basically a form of protection that can be enjoyed in real terms, such as gifts in the form of material or non-material nature. Material gifts can be in the form of compensation or restitution, exemption from living expenses or education. The provision of non-material protection can be in the form of release from threats, from news that demeans human dignity. ${ }^{10}$

A good rule of law will certainly be of no use if it is not enforced. This requires quality resources and supporting facilities or infrastructure. In addition, the support of the wider community is a prerequisite for the realization of fair law enforcement. 11 The values contained in the Precepts of Belief in One Supreme God are the basic ideas in efforts to develop national criminal law. Thus, it is necessary to explore the values of religious law to be integrated in the development of the

\footnotetext{
${ }^{8}$ Sri Kusriyah, Kebijakan Pemerintah Daerah Dalam Pemberdayaan Perempuan di Kabupaten Demak, Jurnal Pembaharuan Hukum, Vol.IV No.1, January-April 2017.

${ }^{9}$ Nurfita A T, Sri Endah Wahyuningsih and Arpangi. The Police Role in Investigating the Crime of Child Murder as a Result of Infidelity Relationships. Law Development Journal ISSN : 2747-2604 Volume 3

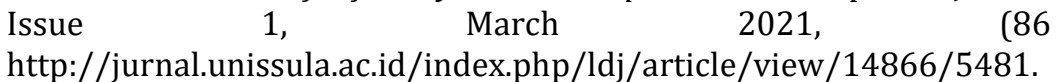

http://jurnal.unissula.ac.id/index.php/ldj/article/view/14866/5481. Kesusilaan Dalam Hukum Pidana Positif Saat Ini, Jurnal Pembaharuan Hukum, Vol.III, No.2 MayAugust 2016.

${ }^{11}$ Achmad Sulchan, Achmad Khisni, Aryani Witasari, Pola Pembinaan Narapidana Yang Berkeadilan (Studi Di Lapas Kedungpane Semarang), Unissula Press, Semarang, 2020,, p.1.
} 
national legal system, including in efforts to reform Indonesia's material criminal law. ${ }^{12}$

The purpose of this study is to find out and analyze the legal protection of victims in the crime of rape, then find out and analyze the obstacles and solutions for the legal protection of victims in the crime of rape.

\section{Research Methods}

The approach method used in this study uses a normative juridical method, namely in addition to using legal principles and principles in reviewing, viewing, and analyzing problems, as they are, ${ }^{13}$ which in this case relates to the legal protection of victims in the crime of rape. The specifications in this study are analytical descriptive. Descriptive research is a research method that is intended to systematically and accurately describe the facts and characteristics of the research field.

Sources of data used in this study are primary, secondary, and tertiary data sources. Primary data sources are objects that are observed directly in the field and interviewed informants. Primary legal materials consist of: KUHP (Book of Criminal Law). Tertiary legal materials consist of dictionaries, encyclopedias.

The data collection method used to obtain data that has a relationship with the object of research is interviews with resource persons and document review, while the data analysis method used is qualitative data analysis in this study including data reduction, data presentation and conclusions/verification.

\section{Result and Discussion}

\subsection{Legal Protection of Victims in the Crime of Rape}

Rape is a crime that gets enough attention among the public. Various kinds of print media such as newspapers, magazines, tabloids or other print media are often reported about the crime of rape. If you study the actual history of this crime, it has existed since ancient times, or it can be said as a form of classic crime that will always follow the development of human culture itself, it will always exist and develop all the time even though it may not be too different from before.

Rape criminal cases most cause difficulties in their resolution, both at the stage of investigation, prosecution, and at the stage of making a decision. In addition to the difficulties in the above limits, there are also difficulties in proving such as rape or obscene acts which are generally carried out without the presence of other people. For this reason, a form of legal protection is needed for victims of the crime of rape.

Legal protection of the rights of victims in the settlement of criminal cases is a phenomenon of Indonesian criminal procedural law, where in its enforcement it will always intersect with law enforcers themselves. Legal protection of the rights

12 Sri Endah Wahyuningsih, Urgensi Pembaharuan Hukum Pidana Materiel Indonesia Berdasarkan Nilai-Nilai Ketuhanan Yang Maha Esa, Jurnal Pembaharuan Hukum, Vol.1 No.1, January-April 2014.

${ }^{13}$ Soerjono Soekanto, 2010, Pengantar Penelitian Hukum, Universitas Indonesia Press, Jakarta, p. 10. 
of victims is very much needed, especially victims in the process of resolving criminal cases who so far feel they are not protected by law, and sometimes there are victims in a criminal case who eventually become suspects.

Legal protection of the rights of victims in the crime of rape in the process of resolving criminal cases, namely: a) legal protection of the rights of victims given is that the security of the victim must be given the best possible service and protected, to maintain the victim's sense of security, comfort and peace either directly or indirectly. b) The District Attorney, that the legal protection of the rights of the victim is carried out by the prosecutor, as in the case where the victim is the child of the prosecutor who fully assists in the trial process and outside the trial. For other cases, the prosecutor looks at the situation or condition of the victim and suggests that the victim ask for further protection from the Police and the Witness and Victim Protection Agency (LPSK); c) District Court, that the legal protection of the victim's rights in court, namely by the way the judge sees the condition or condition of the victim, must be considered properly, seen from the physical injury experienced by the victim. In special criminal cases involving children, the judge looks at the child's age, psychological and physical condition of the child. The rights of victims to be protected by their parents, non-governmental organizations and legal advisors are also considered. All this for the realization of restorative justice.

So far, the regulation of victim protection has not shown a clear pattern, in the positive criminal law currently in effect, victim protection is mostly "abstract protection" or "indirect protection". This means that the various formulations of criminal acts in the laws and regulations so far have essentially provided direct protection against the legal interests and human rights of victims.

Indirect protection in the positive legal regulations has not been able to provide maximum protection. Because the reality in Indonesia shows that the applicable law has not been able to guarantee certainty and a sense of justice.

In Islamic law, rape is known as the concept of (ikrah) intercourse because there is coercion from the perpetrators, both men and women, generally categorized in the crime of adultery and classified in Jarimah Hudud, the punishment for the perpetrator of adultery mukhson is stoning and for the perpetrator of adultery, ghairu mukhson, is stoning. 100 lashes and exiled or expelled from the area.

That Islam commands cleanliness regarding sexual relations, for men and women, at any time before marriage, during marriage and after the termination of the marriage relationship. Those who commit the forbidden act are expelled from the marital environment of respectable men and women.

If this is viewed from the perspective of Islamic law, it is clear that the perpetrator is threatened with a very severe punishment, namely had and the victim is not punished at all. According to the author, the verdict handed down to the perpetrator is not commensurate with the suffering experienced by the victim, it should also be considered regarding the interests and rights of the victim, moreover it can seek compensation in the form of compensation, restitution and rehabilitation for rape victims who experience physical suffering as well as psychological. Such efforts will be able to provide more protection for the rights of victims and can provide a good image for law enforcement in Indonesia. 
With regard to the protection of victims of crime, it is necessary to establish an institution that specifically handles it. However, it is necessary to convey in advance adequate information regarding what rights the victim and her family have, if in the future they experience loss or suffering as a result of the crime that befell them.

In the example case in Decision No.22/Pid.Sus-Anak/2019/PN.Smg, with the defendant Yohan Ashari Poluakan Bin Edi Poluakan, it was legally and convincingly proven guilty of committing a criminal act by intentionally helping to commit violence or threats of violence to force others have sex with him out of wedlock. As a result of his actions, the defendant was sentenced to a prison sentence of 2 (two) years and 6 (six) months at the Class I LPKA (Institute for Child Development) Kutoarjo.

\subsection{Obstacles and Solutions to Legal Protection of Victims in the Crime of Rape}

So far, the obstacles to the legal protection of victims' rights in the process of resolving criminal cases, namely:

- Compensation for the damage done by the defendant materially. The compensation given by the defendant to the victim was not in accordance with what was expected by the victim/his family due to the economic limitations of the defendant. but the family of the suspect/defendant can only replace a few percent;

- For the form of immaterial losses, namely feelings of fear, pain, sadness, psychological shock and so on, in criminal cases it cannot be done.

As it is known that Act No. 8 of 1981, concerning the Criminal Procedure Code, adheres to a criminal justice system that prioritizes the protection of human rights, but if the provisions regarding this matter are considered in more depth, it turns out that only the rights of the suspect are considered. The defendant is highlighted a lot while the rights of the crime victims are very little regulated. In line with this principle, the community, especially the mass media, focuses more on the rights of the suspect/defendant rather than questioning the protection of victims of crime.

Protection of victims of the crime of rape is an activity to develop human rights and human rights obligations. Attention and protection for victims of the crime of rape must be considered because they are very sensitive to various kinds of threats of mental, physical, and social disorders. In addition, they often do not have the ability to maintain, defend and defend themselves.

To protect the victims of the crime of rape, it is necessary to organize the management of the victims of the crime of rape, which includes prevention, therapy and rehabilitation. A person's attention aimed at the victim, family, environment and society at large. It is clear that the management of victims of the crime of rape will involve many people from various disciplines.

Therapy for rape victims requires attention that is not only focused on the victim. In addition to complaints from victims, it is also necessary to hear complaints from families, information from people who helped them for the first time and information from their surroundings. The need for therapy is often caused by family 
or environmental disturbances. The purpose of therapy for rape victims is to reduce or even eliminate their suffering. Besides that, it is also to improve their behavior, increase their ability to create and maintain social relationships. This means that the therapy given must be able to return the victim to his work or activity within the limits of his abilities and habits of his social role.

Protection for victims of the crime of rape cannot be separated from the consequences experienced by victims after rape. Victims do not only suffer physically but also suffer psychologically. The suffering suffered by the victim as a result of rape can be divided into: physical impact, mental impact, impact on personal and social life.

Article 1 Number 6 of Act No. 13 of 2006 concerning the Protection of Witnesses and Victims emphasizes that protection is all efforts to fulfill rights and provide assistance to provide a sense of security to witnesses and/victims that must be carried out by LPSK (Witness and Victim Protection Agency) or other institutions others in accordance with the provisions of this law. The definition of victim protection can be seen from 2 (two) meanings: Defined as legal protection not to become a victim of crime (meaning protection of human rights or one's legal interests) and interpreted as protection to obtain legal guarantees/compensation for the suffering/loss of people victim (identical to victim sponsorship).

The solution to the legal protection of victims in the crime of rape is the rehabilitation of victims of the crime of rape, where physical and psychosocial actions are carried out as an effort to obtain maximum function and adjustment and to prepare victims physically, mentally and socially in their future lives. The goals of rehabilitation include medical, psychological and social aspects. The medical aspect aims to reduce invalidity, and the psychological and social aspects aim towards achieving self-adjustment, self-esteem and also the achievement of healthy views and attitudes from families and communities towards victims of the crime of rape. To achieve this goal, the victims of the crime of rape always get intensive psychiatric medical services.

\section{Closing}

The conclusion of this research is the protection of the victims of the crime of rape in addition to experiencing physical suffering but also experiencing psychological suffering which takes a long time to recover. The obstacles that arise in the legal protection of the rights of victims in the process of resolving criminal cases: a) The criminals themselves, where the perpetrators of the crime are very good at committing crimes so that they are not caught or not caught; b) The attitude of the community, where the attitude of the community is indifferent in dealing with crimes that occur in their environment, so that people are less sensitive in dealing with crimes that occur; c) The compensation given by the perpetrator to the victim is not in accordance with what the victim expects because of the economic limitations of the perpetrator of the crime; d) For immaterial losses in criminal cases it cannot be done. The solution to the legal protection of victims in the crime of rape is the rehabilitation of victims of the crime of rape, where physical and psychosocial actions are carried out as an effort to obtain maximum function and adjustment and to prepare victims physically, mentally and socially in their future lives. 
Suggestions in this study are law enforcement officers in providing services and protection to women victims of rape should be based on a sense of humanity, and in handling rape cases not only use the basis of the Criminal Code but also use laws outside the Criminal Code (not using the suspicion of a single article. The community should also support women victims of violence (rape) to get legal protection, so that the Indonesian nation becomes a country that has succeeded in prospering society based on a sense of humanity.

\section{References}

\section{Journal}

[1] Adhe I smail A, Constitutionalism Concept in Implementation of Indonesian State Administration. Jurnal Daulat Hukum Volume 4 Issue 2, June 2021 ISSN: 2614$560 X$.

[2] Ardito, Y P, Umar Ma'ruf dan Aryani Witasari. Implementation of Criminal Action Prosecution Online in Realizing Principle of Fast Prosecution, Simple \& Low Cost, Jurnal Daulat Hukum, Volume 4 Issue 2, June 2021 ISSN: 2614-560X.

[3] Feri, S W, dan Arpangi. Settlement Policy of Criminal Actions which Performed by Children through Penal Mediation. Jurnal Daulat Hukum Volume 4 Issue 2, June 2021 ISSN: 2614-560X.

[4] Feri, S W, dan Arpangi. Settlement Policy of Criminal Actions which Performed by Children through Penal Mediation. Jurnal Daulat Hukum Volume 4 Issue 2, June 2021 ISSN: 2614-560X.

[5] Indah Lestari, Sri Endah Wahyuningsih, Penegakan Hukum Pidana Terhadap Pengguna Narkoba di Polda Jateng, Jurnal Hukum Khaira Ummah, Vol.2 No.3, September 2017.

[6] Nurfita A T, Sri Endah Wahyuningsih dan Arpangi. The Police Role in Investigating the Crime of Child Murder as a Result of Infidelity Relationships. Law Development Journal ISSN : 2747-2604 Volume 3 Issue 1, March 2021.

[7] Sri Endah Wahyuningsih, Perlindungan Hukum Terhadap Anak Sebagai Korban Tindak Pidana Kesusilaan Dalam Hukum Pidana Positif Saat Ini, Jurnal Pembaharuan Hukum, Vol.III, No.2, May-August 2016.

[8] Sri Kusriyah, Kebijakan Pemerintah Daerah Dalam Pemberdayaan Perempuan di Kabupaten Demak, Jurnal Pembaharuan Hukum, Vol.IV No.1, January- April 2017.

[9] Yusril I A, Bambang Tri Bawono dan Ira Alia Maerani, Criminal Investigation of Motorcycle Stealing Goods. Law Development Journal ISSN : 2747-2604 Volume 3 Issue 1, March 2021

\section{Books}

[1] Achmad Sulchan, Achmad Khisni, Aryani Witasari, 2020, Pola Pembinaan Narapidana Yang Berkeadilan (Studi Di Lapas Kedungpane Semarang), Unissula Press, Semarang.

[2] Lilik Mulyadi, 2004, Kapita Selekta Hukum Pidana Krimonologi dan Viktimologi, Jakarta: Djambatan.

[3] Romli Atmasasmita, 1995, Kepala Selekta Hukum Pidana dan Krimonologi, Bandung: Mandar Maju. 


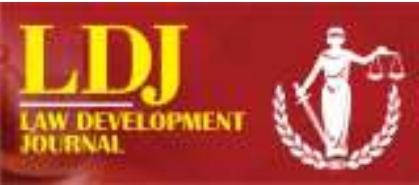

Law Development Journal

ISSN : 2747-2604

Volume 3 Issue 2, June 2021, (353 - 361)

[4] Soerjono Soekanto, 2010, Pengantar Penelitian Hukum, Universitas Indonesia Press, Jakarta. 